\title{
Comparison of Tuberculin Skin Test and QuantiFERON-TB Gold Test in Children
}

\section{Çocuklarda Tüberkülin Deri Testi ve QuantiFERON-TB Gold testinin Karşılaştırılması}

\author{
Seval OZEN¹, Fatih UCKARDES², Hatice UYGUN¹, Nurettin ERDEM ${ }^{1}$, Nevzat AKGUL ${ }^{3}$, Mehmet TURGUT ${ }^{1}$
}

${ }^{1}$ Adiyaman University Medical Faculty Pediatric Infectious Diseases Department, Adiyaman, Turkey

${ }^{2}$ Adiyaman University Department of Biostatistics and Medical Informatics, Adiyaman, Turkey

${ }^{3}$ Adiyaman Directorate of Health, Tuberculosis Control Dispensary, Adiyaman, Turkey

\begin{abstract}
Objective: Interferon- $\gamma$ release tests (IGRAs) and tuberculin skin testing (TST) are important helpful tests for diagnosing tuberculosis (TB) disease in children. It was aimed to compare the sensitivity and compatibility of QuantiFERON-TB Gold In-tube test (QFT) and TST used in children with TB and Latent tuberculosis infection (LTBI).

Material and Methods: A total of 118 patients between September 2018 and January 2020 were included in the study prospectively to determine the case characteristics related to the performance of the tests, and to measure the sensitivity of these tests.

Results: A total of 118 patients were included in the study; and $13(11 \%)$ patients presented with pneumonia symptoms and 7 (6\%) patients were diagnosed with TB in active TB Contact Screening. TB diagnosis was made 20\% microbiologically. Mycobacterium tuberculosis culture positivity was found to be $10 \%$. None of the patients had acidresistant bacilli positivity. The male / female rate was $74 / 44$ in our study $(p=0.006)$. The median age was found to be 14 (1.17-19.2 years) in males, and 12 (0.33 -17.9 years) in females. The mean age of the LTBI Group was higher than the TB Group at significant levels ( $p<0.05)$, and was similar to the non-infected group ( $p>0.05)$. A total of $53.5 \%$ of the patients had a history of meeting someone with tuberculosis, and 97 children were vaccinated with BCG (82.2\%). TST and QFT positivities were $19.5 \%$ and $22 \%$, respectively. The most common radiological finding that was detected was consolidation areas. While there was moderate compliance between TST and IGRA test in patients with TB diagnosis (kappa $=0.50, p=0.025$ ), no compliance was found between tests in LTBI patients. In patients who were diagnosed with TB and LTBI, the sensitivity of TST was found to be $51.1 \%$, and the sensitivity of QFT was found to be $60.4 \%$.

Conclusion: TST seems to continue as the most preferred method of diagnosis in rural areas with limited resources and poor laboratory infrastructure due to the costs and technical considerations.

Key Words: Interferon Gamma Release Test, Latent Tuberculosis, Tuberculin Skin Test, Tuberculosis

öz

Amaç: Interferon- $\gamma$ salınım testleri (IGRA'lar) ve tüberkülin deri testi (TST) çocuklarda tüberküloz (TB) hastalığının teşhisi için önemli yardımcı testlerdir. Bu çalş̧mada, TB ve latent tüberküloz enfeksiyonu (LTBI) olan çocuklarda kullanılan QuantiFERON-TB Gold In-tube testi (QFT) ile tüberkülin deri testinin (TST) duyarlığının ve uyumunun karşılaştıııması amaçlandı.
\end{abstract}

\footnotetext{
(1)

0000-0001-8342-3786: OZEN S 0000-0003-0677-7606: UCKARDES F 0000-0002-8695-9129: UYGUN H 0000-0003-4061-4675: ERDEM M 0000-0001-5914-7419: AKGUL N 0000-0002-2155-8113: TURGUT M

Conflict of Interest / Çıkar Çatışması: On behalf of all authors, the corresponding author states that there is no conflict of interest.

Ethics Committee Approval / Etik Kurul Onayı: This study was conducted in accordance with the Helsinki Declaration Principles. Approval was obtained from Adiyaman University, Faculty of Medicine, Ethics Board with the decision number 2018/6-10.

Contribution of the Authors / Yazarların katkısı: OZEN S: Constructing the hypothesis or idea of research and/or article, Taking responsibility in patient follow-up, collection of relevant biological materials, data management and reporting, execution of the experiments, Taking responsibility in the writing of the whole or important parts of the study. UCKARDES F: Taking responsibility in logical interpretation and conclusion of the results. UYGUN H: Taking responsibility in patient follow-up, collection of relevant biological materials, data management and reporting, execution of the experiments. ERDEM M: Taking responsibility in patient follow-up, collection of relevant biological materials, data management and reporting, execution of the experiments. AKGUL $\boldsymbol{N}$ : Taking responsibility in patient follow-up, collection of relevant biological materials, data management and reporting, execution of the experiments. TURGUT M: Constructing the hypothesis or idea of research and/or article, Planning methodology to reach the Conclusions, Organizing, supervising the course of progress and taking the responsibility of the research/study, Reviewing the article before submission scientifically besides spelling and grammar.

How to cite / Atıf yazım șekli : Ozen S, Uckardes F, Uygun H, Akgul N and Turgut M. Comparison of Tuberculin Skin Test and QuantiFERON-TB Gold Test in Children. Turkish J Pediatr Dis 2022;16:362-367.
}

Correspondence Address / Yazışma Adresi:

Seval OZEN

Adiyaman University Medical Faculty,

Pediatric Infectious Diseases Department, Adiyaman, Turkey

E-posta: drsevalcevik@hotmail.com
Received / Geliş tarihi : 07.09.2021 Accepted / Kabul tarihi : 09.11.2021 Online published Elektronik yayın tarihi

DOI: 10.12956/tchd.984653 
Gereç ve Yöntemler: Eylül 2018-Ocak 2020 tarihleri arasında testlerin performansıyla ilişkili vaka özelliklerini belirlemek ve testlerin duyarlıı̆ıını ölçmek için 118 hasta prospektif olarak çalışmaya dahil edildi. TST ve QFT testleri eşzamanlı yapıldı.

Bulgular: Çalışmaya 118 hasta dahil edildi. Pnömoni semptom ve bulguları ile başvuran 13 (\%11), aktif TB temaslı taramasında 7 (\%6) hasta TB tanısı aldı. TB tanısı \%20 mikrobiyolojik, \%80 klinik olarak konuldu. Semptomatik hastalık nedeniyle 50 (\%42.3) çocuktan açlık mide sıvısında tüberküloz belirteçleri çalışıldı. Mycobacterium tuberculosis kültür pozitifliği ise \%10'du. Hiçbir hastamızda asidorezistan basil pozitifliği saptanmadı. Çalışmamızda erkek / kadın oranı 74/44'dı. Ortanca hasta yaşı erkeklerde 14 yıl (1.17-19.2 yıl), kızlarda ise 12 yıl (0.33 - 17.9 yıl)'dı. LTBI grubunun yaş ortalaması TB grubundan anlamlı olarak yüksekken $(p<0.05)$ enfekte olmayan grup ile benzerdi (p>0.05). Hastaların \% 53.5'inde tüberkülozlu biriyle karșılașma öyküsü vardı ve \% 82.2'sinde BCG așısı yapılmıștı. Saptanan en sık radyolojik bulgu konsolidasyondu. TB tanılı hastalarda TST ile IGRA testi arasında orta düzeyde (kappa =0.50, p=0.025) uyum saptanırken LTBI hastalarında testler arasında uyum saptanamadı. TB ve LTBI tanılı hastalarda TST'nin sensitivitesi \%51.1 (\%95 CI,36.7-65.3), QFT'nın sensitivitesi \%60.4 (\%95 Cl,45.5-73.6)'dı.

Sonuç: Maliyet ve teknik hususlar, sınırlı kaynaklara ve zayıf laboratuvar altyapısına sahip kırsal bölgelerde tanıda TST en çok tercih edilen yöntem olarak devam edecek gibi gözükmektedir.

Anahtar Sözcükler: İnterferon gama salım testi, Latent tüberküloz, Tüberkülin deri testi, Tüberküloz

\section{INTRODUCTION}

The definitive diagnosis of tuberculosis (TB) disease in children is made by demonstrating the bacillus microbiologically. The diagnosis is called "bacteriological diagnosis" in case the bacillus is shown, and "clinical diagnosis" when it cannot be shown. Unlike in adults, the rate of showing bacillus is very low in children. In case the bacillus cannot be shown, the contact history of the child with infectious TB patients, clinical and radiological findings, Tuberculin Skin Test (TST), and Interferon- $\gamma$ Release Test (IGRA) positivity are evaluated together, and the diagnosis is made in this way. For this reason, TST and IGRA play important roles in the decision to initiate the treatment for pediatric TB (1-3).

TST has been employed in supporting the diagnosis when TB is suspected. However, the sensitivity of TST is limited in severe forms of TB. For example, TST-positive results are detected only in $60 \%$ of patients with proven TB meningitis. The specificity of TST is also insufficient as non-tuberculosis mycobacterial infection and Bacille Calmette-Guerin (BCG) vaccination may yield false positive TST results (4).

IGRAs have superior test specificity compared to TSTs; however, the data on their sensitivity in children with TB, especially in those $<5$ years old, are limited (2).

In the present study, the purpose was to compare the performance of IGRA and TST in patients with active TB contacts, those who had tuberculosis symptoms, those who admitted to a tertiary pediatric hospital, and those referred to detect possible Mycobacterium Tuberculosis infection before using immunosuppressive drugs.

\section{MATERIAL and METHODS}

A total of 118 patients who were examined for TB between September 2018 and January 2020 were included in the study prospectively. The patients were divided into 3 groups. Patients who had TB symptoms and / or abnormal radiological imaging results, those who had active TB contact, and those who admitted with other reasons (e.g., before using biological agents) were examined for TB. The IGRA and TST were performed for all patients. Patients for whom the tests were not applied simultaneously were excluded from the study. We examined the medical records of patients, and collected the data on their demographic, clinical, microbiological and radiological examinations, and on the presence of BCG Scar and $B C G$ vaccination history. Complete clinical evaluations were performed for all patients.

TST (Mantoux Test). In the Tuberculosis Dispensary or in our hospital, $0.1 \mathrm{ml}$ (5 IU) Tuberculin Solution (PPD-S Tween 80) was applied with a 26-No needle to the dry skin in the 1/3 upper front area of the left forearm. The diameter of the induration that appeared at the test site 72 hours after injection was measured as millimeter $(\mathrm{mm})$. Interpretation of the tuberculin test; in children who are not vaccinated with BCG; TST reaction positive if $\geq 10 \mathrm{~mm}$, negative if $<10 \mathrm{~mm}$; children with $B C G$ vaccine were considered positive if $\geq 15 \mathrm{~mm}$ and negative if $<$ $15 \mathrm{~mm}$ (5).

IGRA Test. This test was done according to the manufacturer's recommendations, and the results were evaluated as summarized below. One $\mathrm{ml}$ venous blood sample was taken from the patients into Nil Control, Mitogen Control, and TB Antigen Tubes that were included in the kit. The tubes were shaken gently 10 times and were then incubated at $37^{\circ} \mathrm{C}$ for 16-24 hours. After the incubation, the RCF was centrifuged at 2200 to $2300 \mathrm{~g}$ for 15 minutes, the plasmas were taken, and the amount of IFN- $\gamma$ (IU / ml) was measured with ELISA. The analyzes of the optical density values were made by using the "QuantiFERON-TB Feron Analysis Software"; and the results of the analyses were evaluated as positive, negative, or undetermined (6).

Latent TB Infection (LTBI) was defined as an asymptomatic child who had a positive TST and / or IGRA result but with a chest 
X-ray not suggesting TB. Active TB was defined as symptoms suggesting TB, abnormal chest $X$-ray results consistent with TB, acid-resistant bacilli stain(ARB) from clinical samples, Nucleic Acid Amplification Test (NAAT), or Mycobacterium tuberculosis positivity in culture.

Symptoms suggesting TB were identified as a cough that lasted more than two weeks, persistent fever, night sweating, weight loss, lymphadenopathy, hydrocephalus, seizure, and cranial nerve involvement.

According to the disease site, the definitions were made as Pulmonary, Central Nervous System (CNS), Extrapulmonary, and Multifocal (> 1 region) TB.

Laboratory verified disease included children with ARB, NAAT, or Mycobacterium tuberculosis culture positivity. All cases who did not meet bacteriological confirmation criteria, but had pathological images in chest $\mathrm{X}$-rays and who had a positive response to specific anti-tuberculosis treatment were accepted as clinical TB.

All contacted children were followed-up at home with 3-month intervals for 12 months by trained field employees, repeated symptom screenings were done, and clinical visits were paid if the child became ill.

Children who were diagnosed with active TB were followed-up clinically with 2-month intervals and at the end of TB treatment to evaluate their response to treatment.

Informed consent forms were obtained from the families for the study.

Approval was obtained from Adıyaman University, Faculty of Medicine, Ethics Board with the decision number 2018/6-10.

\section{Statistical Analyses}

The Statistical Package for the Social Sciences 15.0 program (SPSS Inc., Chicago, IL, USA) was used for the statistical analyses. The One-Sample Kolmogorov-Smirnov test was used to determine whether the continuous data were distributed normally. Groups were compared using the One-Way ANOVA or the Kruskal Wallis $\mathrm{H}$ test whichever one was appropriate. As a result of these analyses, the groups which were found significant were compared with the Tukey's Multiple Range Test or Mann Whitney U test (Bonferroni Correction was applied for $p$ values $<0.0167$ (i.e., and 0.05/3 comparisons). The results were reported as Mean \pm SD or median (Min-Max). Categorical variables were compared using the Chi-Square Test or Fisher's Exact Chi-Square Test whichever was appropriate, and were expressed as numbers and percentages. The Cohen's Kappa Statistic was used for the agreement test. $p$ value $<0.05$ was considered statistically significant.

\section{RESULTS}

The flow diagram of the study is given in Figure 1. A total of 13 (11\%) patients who admitted with pneumonia symptoms and findings, and 7 (6\%) patients in active TB contact screening were diagnosed with TB. LTBI was detected in 23 (19.5\%) patients; and 75 (63.5\%) children were not infected.

Clinical and demographic details are given in Table I.

The male / female rate was $74 / 44$ in our study ( $p=0.006$ ). The median age was found to be 14 (1.17-19.2 years) in males, and 12 (0.33 - 17.9 years) in females.

When the 3 groups were compared in terms of age, it was found that there were significant differences $(p<0.01)$. The mean age of the LTBI Group was higher than that of the TB Group at significant levels $(p<0.05)$, and was similar to that of the non-infected group ( $p>0.05)$ (Table II).

When the 3 groups were compared in terms of TST, it was found that there were significant differences $(p<0.001)$. The median TST of the LTBI and TB Groups were higher than that of the non-infected group at significant levels $(p<0.0167)$, and was similar to that of the median TST of the LTBI and TB Groups ( $p>0.05$ ) (Table II).

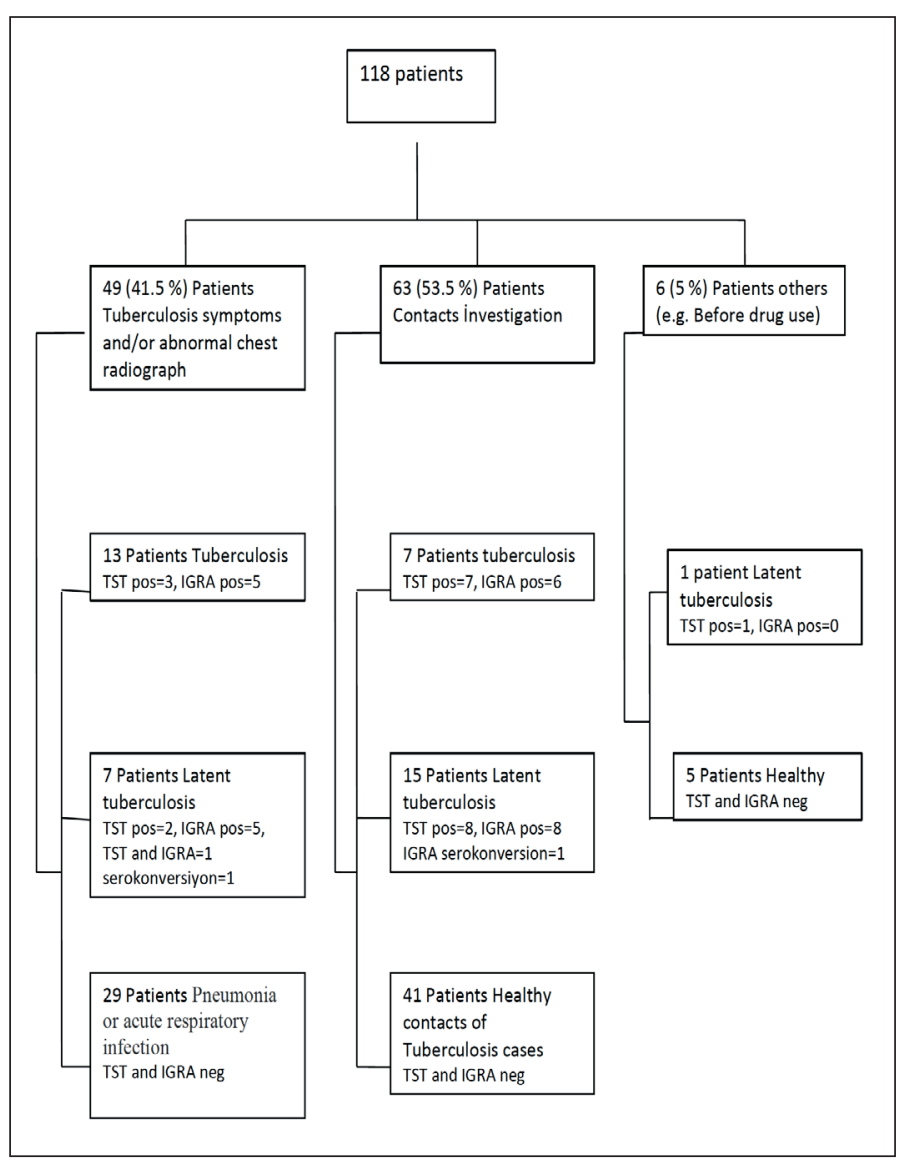

Figure 1: The outline of the study design. 
Table I: Characteristics of children enrolled in the study $(n=118)$.

\begin{tabular}{|c|c|}
\hline Characteristic & n (\%) \\
\hline Male & $74(62.7 \%)$ \\
\hline Age (yrs), median (min-max) & $13.4(1.1-19.2)$ \\
\hline BCG vaccinated & 97 (82.2\%) \\
\hline BCG non-vaccinated & $21(17.8 \%)$ \\
\hline TST/IGRA test performed & $118(100 \%)$ \\
\hline $\begin{array}{l}\text { Culture or/and Nucleic acid amplification } \\
\text { (NAAT) method performed }(\mathrm{n}=20) \\
\text { Acid fast staining positive } \\
\text { Culture positive (M. tuberculosis) } \\
\text { NAAT positive } \\
\text { Pathology positive }\end{array}$ & $\begin{array}{l}- \\
2(10 \%) \\
1(5 \%) \\
1(5 \%)\end{array}$ \\
\hline $\begin{array}{l}\text { Site of disease } \\
\text { Pulmonary TB only } \\
\text { CNS disease } \\
\text { Extrapulmonary only } \\
>1 \text { site } \\
\text { Pulmonary and extrapulmonary } \\
\text { Pulmonary and CNS disease }\end{array}$ & $\begin{array}{l}11(55 \%) \\
1(5 \%) \\
3(15 \%) \\
5(25 \%) \\
4(75 \%) \\
1(25 \%)\end{array}$ \\
\hline $\begin{array}{l}\text { Radiological examination performed } \\
\text { Radiological findings } \\
\text { Consolidation } \\
\text { Cavitary lesion } \\
\text { Mediastinal lymphadenopathy } \\
\text { Consolidation and bronchiectasis } \\
\text { Pleural effusion } \\
\text { Abdominal mesenteric lymphadenopathy }\end{array}$ & $\begin{aligned} 13 & (13.5 \%) \\
3 & (3.1 \%) \\
4 & (4.1 \%) \\
2 & (2 \%) \\
2 & (2 \%) \\
1 & (1 \%)\end{aligned}$ \\
\hline $\begin{array}{l}\text { Disease confirmation criteria }(n=20) \\
\text { Laboratory } \\
\text { Clinical }\end{array}$ & $\begin{array}{r}4(20 \%) \\
16(80 \%)\end{array}$ \\
\hline
\end{tabular}

BCG: Bacille Calmette-Guerin, TST: Tuberculin Skin Test, IGRA: Interferon- $\gamma$ release tests, TB: Tuberculosis, CNS: Central Nervous System.
A total of 97 children were vaccinated with BCG (82.2\%). Because of symptomatic disease, ARB, Mycobacterium tuberculosis culture, and / or NAAT were examined in fasting gastric fluid of 50 (42.3\%) children. A total of 20 children were diagnosed with TB; 11 had pulmonary TB, and only one of these had positive culture, TST was negative, and IGRA was positive; CNS TB was detected in 1, TST and IGRA were negative, and NAAT was positive; extra-pulmonary TB was detected in 3; and 5 were diagnosed with multifocal TB. Culture, TST and IGRA were positive in 2 patients diagnosed with Multifocal TB.

The IGRA and TST tests were performed together on 118 patients. Positive TST was recorded in 23 (19.5\%) patients who were tested, and the induration size ranged between 10 and $20 \mathrm{~mm}$. IGRA positivity rate was 26 (22\%). When two patients who had a history of domestic contact were evaluated again, immunological transformations were detected in IGRA and TST (from zero to $16 \mathrm{~mm}$ ) in one patient, and only in IGRA in the other patient.

The first-line radiological imaging results were evaluated with postero-anterior Chest X-rays. Computed Tomography was performed on 29 (24.5\%) patients who had abnormal radiological imaging results. Although the most common radiological finding was consolidation areas in patients diagnosed with pulmonary $\mathrm{TB}$, cavitary lesions were detected in the lungs of 3 patients.

While there was moderate compliance between TST and IGRA test in patients with TB diagnosis (kappa $=0.50, P=0.025$ ), no compliance was found between tests in LTBI patients.

The sensitivity of TST was found to be 51.1\% (95\% Cl, 36.765.3), and the sensitivity of IGRA was 60.4\% (95\% Cl, 45.573.6) in patients diagnosed with TB and LTBI.

Table II: Age and Sex Distribution of Study Patients.

\begin{tabular}{l|c|c|c|c|c|c|c|}
\hline & $\begin{array}{c}\text { Patient number } \\
\mathbf{n}(\%)\end{array}$ & $\begin{array}{c}\text { Mean age } \\
\text { (years) }\end{array}$ & $\begin{array}{c}\text { Std. } \\
\text { deviation }\end{array}$ & $\begin{array}{c}\text { Minimum } \\
\text { age (years) }\end{array}$ & $\begin{array}{c}\text { Maximum age } \\
\text { (years) }\end{array}$ & $\begin{array}{c}\text { Median age } \\
\text { (years) }\end{array}$ & $\mathbf{p}^{*}$ \\
\hline Boys & $74(62.7 \%)$ & 13.2 & 3.56 & 1.17 & 19.2 & 14 & 0.033 \\
Girls & $44(37.3 \%)$ & 11.7 & 4.11 & 3.33 & 17.9 & 12 & 0.033 \\
\hline Total & $118(100 \%)$ & 12.6 & 3.83 & 1.17 & 19.2 & 13.41 & \\
\hline
\end{tabular}

*Mann-Whitney $U$ test

Table III: Three Intragroup Comparison in terms of Age, Gender, Presence of BCG Scar, and Tuberculin Skin Test Measurements.

\begin{tabular}{|c|c|c|c|c|}
\hline & Non-Infected $(n=75)$ & LTBI $(n=23)$ & TB $(n=20)$ & $p$ \\
\hline Age $^{*}$ & $12.58^{\mathrm{ab}} \pm 3.47$ & $14.52^{\mathrm{a}} \pm 2.91$ & $10.93^{b} \pm 4.95$ & 0.002 \\
\hline Gender $^{\dagger}(\mathrm{E} / \mathrm{K})$ & $51 / 24$ & $14 / 9$ & $9 / 11$ & 0.164 \\
\hline TST $(\mathrm{mm})^{\ddagger}$ & $0(0-14)^{c}$ & $13(0-20)^{d}$ & $12.5(0-20)^{d}$ & $<0.001$ \\
\hline
\end{tabular}

*:One Way ANOVA test, ab: Means within the same row with different superscripts are significantly different ( $p<0.05$, Tukey's test ), $t:$ Chi square

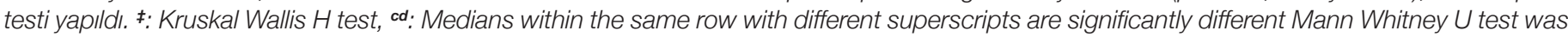
used for multiple comparison (Bonferroni correction was applied for which p-values $<0.0167$ (i.e., 0.05/3 comparisons). LTBI: Latent Tuberculosis, TB: Active Tuberculosis, BCG: Bacille Calmette-Guerin, TST: Tuberculin Skin Test. 
Table IV: Comparison of the Results of QuantiFERON-TB gold In-Tube and TST.

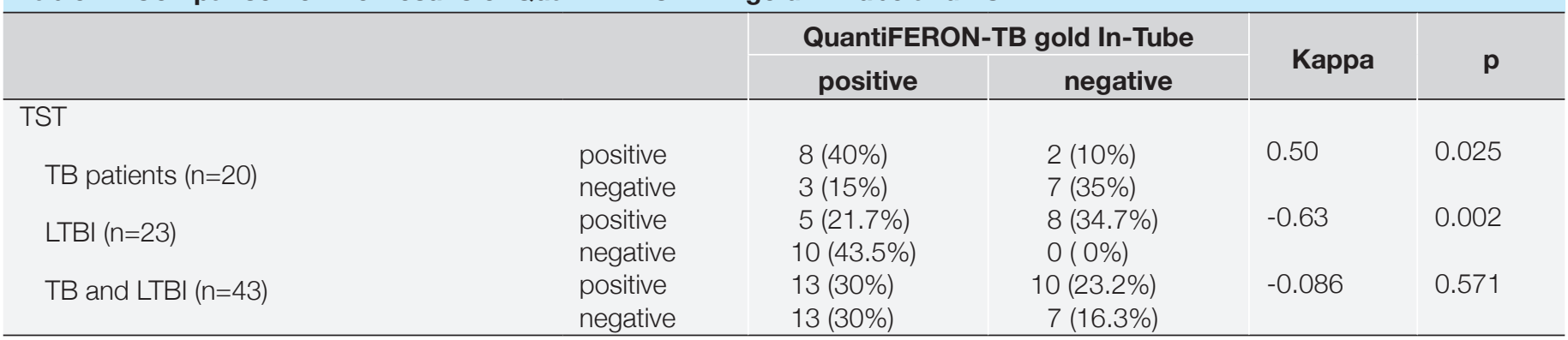

TST: Tuberculin Skin Test, TB: Tuberculosis, LTBI: Latent Tuberculosis, TB: Active Tuberculosis .

\section{DISCUSSION}

The low rate of bacteriological confirmation and test positivity in pediatrics continues to be a problem in active TB disease due to the paucibacillary nature of the disease and the relative difficulties in collecting sufficient specimens for microbiology (7). Many children who have clinical TB do not have microbiologically proven TB. In many studies, clinical TB diagnosis, which is a less reliable method, is employed $(4,8)$. In our study, although we had $20 \%$ patients with microbiological evidence, we could not detect ARB positivity in any of our cases. We believe that this was because of the lack of our laboratory experiences or the patient group's being a pediatric age group, and perhaps due to insufficient samples.

Although IGRA tests yielded promising results in many studies, there are few published articles on their performance in children. Current studies suggest that these tests may be used and may also be clinically useful in evaluating TB in children in some cases. Kay et al. (2) found in their study that IGRA sensitivity was similar to that of TST in children under 5 years of age, but the sensitivity of these tests decreased in children who were younger than 2 years of age, undetermined results were higher in children who were younger than 1 year of age and in the presence of a Central Nervous System disease. It was also reported in the same study that IGRA had more sensitivity than TST in children who were $\geq 5$ years old and who had laboratory-approved TB and must be considered as the preferred immunodiagnostic test (2). In the study conducted by Ahmed et al. (9), the sensitivity of TST and IGRA were reported as 50\% and $75 \%$, respectively. Connell et al. (10) reported that although high-level compliance was detected between IGRAs in their study, there was no compliance between IGRAs and TST. It was found in another study that the sensitivity of the QuantiFERON-TB Gold In-tube Test was 92\%, the compliance between IGRAs was high, and IGRAs were also compatible with TST (11). In our study, the sensitivity of TST was $51 \%$, and that of IGRA was $60 \%$ in patients diagnosed with TB and LTBI. Eight of our 10 TST-positive TB patients were also found to be IGRA positivity, and cohen-kappa analysis between the tests showed moderate agreement. We think that the small number of patients with a diagnosis of TB in our study population and the small number of patients with microbiological evidence may affect this result and this is a limitation of our study. However, there was no agreement between TST and IGRA tests in our LTBI patients. In only 5 of our 23 LTBI patients, both tests were positive at the same time. TST was positive in 13 patients, while IGRA was positive in 15 patients. IGRAs are increasingly being recommended as a replacement for TST. Is the reason for this discrepancy in our study, false positive TST or false negative IGRA? Considering the disadvantages of both tests, it seems to be an important question that may affect the practical use of the tests.

Studies speculated that IFN- $\gamma$ may be required to predict active TB in countries where the TB burden is high and where the combination of other risk factors with IGRA results has a much higher predictive value than IFN- $\gamma$ response alone, but is not sufficient on its own (11-13). Based on the current data, a negative IGRA does not exclude active TB, and it is not recommended that IGRA is used as a single tool to confirm or exclude active TB in children. IGRA positivity was 55\%, TST positivity was $50 \%$, and the positivity of both tests was $40 \%$ in our patients diagnosed with TB. Also, some authors argue that IGRA, which is initially negative, must be repeated in patients if clinicians plan to start TB treatment. When the tests were evaluated again in our 2 patients who had a history of domestic contact, the immunological transformation was detected in both IGRA and TST (from 0 to $16 \mathrm{~mm}$ ) in one patient, and only in IGRA in the other patient (14). If one of the tests is positive, it is considered in favor of LTBI. If the target of requesting the test is sensitivity, one of these tests can be employed. We believe that the diagnosis can be continued to be made with TST under the conditions of our country, except for the cases for whom sensitivity is very important, who have a high suspicion of TB, for children with risk factors for TB, and for patients who will receive immunomodulatory biological agents in a short time.

Studies show the importance of even one single case in detecting the disease and the contact in TB $(15,16)$. In the present study, 7 patients (11\%) were diagnosed with TB in active tuberculosis contact screening, and 13 patients (20\%) were detected to have LTBI. Programs to fight against tuberculosis must be continued 
without interruptions. We believe that finding active cases and contacts should be considered among the close contacts of infectious TB cases in countries with moderate and high TB burden, and careful follow-ups are needed to detect additional tuberculosis and latent tuberculosis cases that may progress to tuberculosis in childhood.

Our study had limitations that deserve discussion. The most important limitation was that only 4 (20\%) patients could be diagnosed with TB based on microbiological evidence in the sampling size that consisted of 118 patients. We could not predict the sensitivity of the QFT and TST Tests because of the small number of TB cases that were microbiologically confirmed. We analyzed the sensitivity of the tests in children with TB and LTBI to overcome this limitation partially. Also, we could not measure important covariates (e.g., nontuberculous mycobacterium infection, HIV infection, and malnutrition), which would enable us to evaluate the performance of these tests better.

When compared with TST, IGRA had higher sensitivity. IGRAs have the advantage of not having cross-reactions with BCG vaccine or non-TB mycobacterial proteins. However, problems that occur due to the production of the test, collection of samples, delay in the isolation and incubation of cells, improper shaking of the test tubes, problems that occur due to the laboratory, or immunological problems caused by possible booster response of the recently performed TST still remain as the disadvantages (17).

As a conclusion, cost and technical considerations might support the selection of TST in rural areas that have limited resources and poor laboratory infrastructure. Multicentric, prospective, and large-scale studies are required with microbiologically proven patient groups to determine our test priority in the conditions of our country.

\section{REFERENCES}

1. World Health Organization, Global Tuberculosis Report 2015, World Health Organization, Geneva,Switzerland, 20th edition, 2015,http://www.who.int/tb/publications/global_report/en/.

2. Kay AW, Islam SM, Wendorf K, Westenhouse J, Barry PM. Interferon- $\gamma$ release assay performance for tuberculosis in childhood. Pediatrics 2018;141:e29728429.
3. Graham SM, Cuevas LE, Jean-Philippe P, Browning R, Casenghi $M$, Detjen AK, et al. Clinical case definitions for classification of intrathoracic tuberculosis in children: an update. Clin Infect Dis 2015; 15: 179-87.

4. Chiang SS, Starke JR. Mycobacterium Tuberculosis. In: Long SS, Prober CG, Fischer M (eds). Principles and Practice of Pediatric Infectious Disease. 5th ed. Philadelphia: Elsevier 2018:4026-81.

5. T.C. Ministry of Health Tuberculosis Diagnosis and Treatment Guide Akdağ R. (eds) Ankara 2011.

6. Mazure GH, Jereb J, LoBue P, lademarco MF, Vernon A. Guidelines for Using the QuantiFERON®-TB G Test for Detecting Mycobacterium tuberculosis Infection, United States. MMWR Recomm Rep 2005;16:49-55.

7. Starke JR. Diagnosis of tuberculosis in children. Pediatr Infect Dis J 2000;19:1095-96.

8. Starke JR. Interferon release assay for diagnosis of tuberculosis infection and disease in children. Pediatrics 2014;134:1763-73.

9. Ahmed A, Feng PJ, Gaensbauer JT, Reves RR, Khurana R, Salcedo K et al. Interferon- $\gamma$ release assays in children $<15$ years of age. Pediatrics 2020;145:e20191930

10. Connell TG, Ritz N, Paxton GA, Buttery JP, Curtis N, Ranganathan SC. A three-way comparison of tuberculin skin testing, QuantiFERON-TB gold and T-SPOT. TB in children. PloS One 2008;3:2624.

11. Tavast E, Salo E, Seppälä I, Tuuminen T. IGRA tests perform similarly to TST but cause no adverse reactions: pediatric experience in Finland. BMC Res Notes 2009;2:9.

12. Rangaka MX, Wilkinson KA, Glynn JR, Ling D, Menzies D, Kambafwile JM, et al. Predictive value of interferon- $\gamma$ release assays for incident active tuberculosis: a systematic review and meta-analysis. Lancet Infect Dis 2012;12:45-55.

13. Togun TO, Egere U, Gomez MP, Sillah AK, Daramy M, Tientcheu $L D$, et al. No added value of interferon- $\gamma$ release to a prediction model for childhood tuberculosis. Eur Respir J 2016;47:223-32.

14. Kampmann B, Whittaker E, Williams A, Walters S, Gordon A, Alier $\mathrm{NM}$, et al. Interferon- $\gamma$ release assays do not identify more children with active tuberculosis than the tuberculin skin test. Eur Respir J 2009;33:1374-82.

15. Schepisi MS, Motta I, Dore S, Costa C, Satgiu G, Giordi E. Tuberculosis transmission among children and adolescents in schools and other congreate settings: a systemic rewiew. New Microbiol 2018;41:282-90.

16. Kim D, Lee S, Kang SH, Park MS, Yoo S, Jeon TY, et al. A contact investigation after exposure to a child with disseminated tuberculosis mimicking inflammatory bowel disease. Korean $\mathrm{J}$ Pediatr 2018;61:366-70.

17. Pai M, Denkinger CM, Kik SV, Rangaka MX, Zwerling A, Oxlade O, et al. Gamma interferon release assays for detection of Mycobacterium tuberculosis infection. Clin Microbiol Rev 2014;27:3-20. 